\title{
S-Methylation of Polythiolactam: Chemical Transformation of Macrocyclic Anion Receptor into New Macrocyclic Ligand for Metal Ions
}

\author{
Junichi Sawada, ${ }^{a}$ Ken Okamoto, ${ }^{\mathrm{a}, \mathrm{b}}$ Takakazu Yamamoto ${ }^{\mathrm{a}}$ and Takaki Kanbara ${ }^{\mathrm{b}, \mathrm{c}^{*}}$ \\ ${ }^{a}$ Chemical Resources Laboratory, Tokyo Institute of Technology, 4259 Nagatsuta, Midori-ku, Yokohama, 226-8503, Japan \\ ${ }^{b}$ Tsukuba Research Center for Interdisciplinary Materials Science (TIMS), University of Tsukuba, 1-1-1 Tennoudai, Tsukuba 305-8573, \\ Japan \\ ${ }^{c}$ Graduate School of Pure and Applied Sciences, University of Tsukuba, 1-1-1 Tennoudai, Tsukuba 305-8573, Japan
}

Abstract - The $S$-methylation of a macrocyclic tetrathiolactam afforded a new macrocyclic thioimidate that exhibited good affinity toward metal ions. The molecular structures of the macrocyclic ligand and its metal complexes were determined by X-ray crystallography. (C) 2009 Elsevier Science. All rights reserved

Macrocyclic compounds often have molecular recognition abilities. ${ }^{1}$ Polylactams (i.e., macrocyclic amides) have recently received considerable interest as hydrogen bonding donors due to their ability to include anions and organic molecules, ${ }^{2}$ whereas macrocyclic compounds containing $\mathrm{N}=,-\mathrm{O}-$, and $-\mathrm{S}-$ groups form useful inclusion complexes with metal ions, and their widespread applications in molecular recognition and metal ion transport are expected. $^{3}$
Bowman-James's group and our group previously demonstrated that the thionation of polylactams enhances the hydrogen donor ability of the hydrogen in the $\mathrm{N}-\mathrm{H}$ group, and the obtained polythiolactams (i.e., macrocyclic thioamides) exhibited strong affinity toward anions. ${ }^{4} \mathrm{We}$ here report the further chemical transformation of polythiolactam, which is effective for inverting the inclusion ability of the macrocyclic compound and provides a new macrocyclic ligand for metal ions.

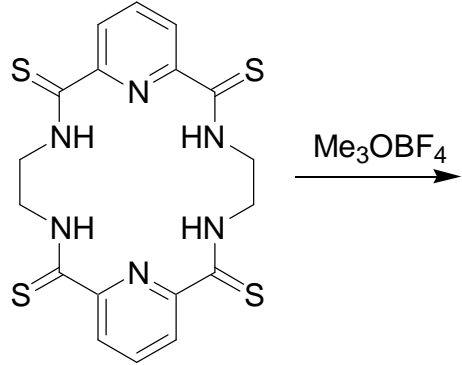

1

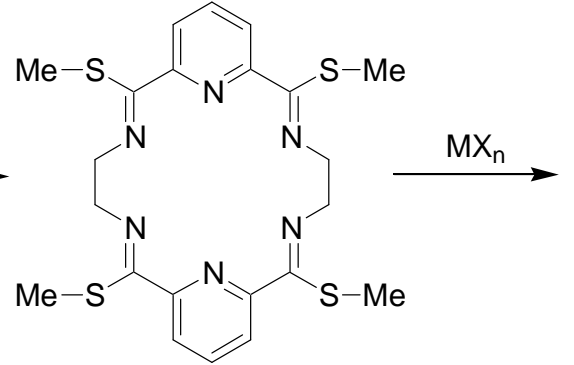

2

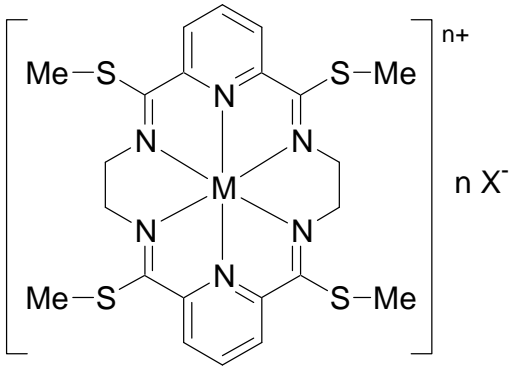

$[2 \cdot M] X_{n}$

Scheme 1

Keywords: macrocycle; thioamide; thioimidate; metal complexes.

${ }^{*}$ Corresponding author. Tel.: +81-29-853-5066; fax: +81-29-853-4490; e-mail: kanbara@ims.tsukuba.ac.jp. 
Secondary thioamides have often been used as versatile intermediates for synthetic applications in medical and organic chemistry, ${ }^{5}$ and it is known that the $S$-alkylation of secondary thioamides yields thioimidates. ${ }^{6}$ This situation prompted us to carry out the $S$-methylation of polythiolactam $\mathbf{1}$ to yield a new macrocyclic thioimidate 2 , as shown in Scheme 1. 2 has six nitrogen lone pair electrons facing the cavity and is expected to exhibit strong affinity toward metal ions. Metal complexes of macrocyclic ligands with Schiff base units have extensively been studied, 3,7 and lanthanide(III) complexes with macrocyclic hexaaza Schiff base ligands are known to act as a catalyst for RNA cleavage. ${ }^{8}$ However, studies of macrocyclic ligands containing the thioimidate group remain rare. ${ }^{9}$ In this paper, preparation and molecular structures of metal complexes of $\mathbf{2}\left([2 \cdot \mathrm{M}] \mathrm{X}_{\mathrm{n}}\right)$ are presented.

1 was prepared as previously reported. ${ }^{4 a}$ The $S$-methylation of 1 with trimethyloxonium tetrafluoroborate $\left(\mathrm{Me}_{3} \mathrm{OBF}_{4}\right)$ afforded 2 in moderate yield $(60 \%),{ }^{10}$ whereas a similar reaction with a related polylactam 3 did not give the corresponding macrocyclic imidate. The treatment of $\mathbf{2}$ with metal salts readily provided metal complexes, $[2 \cdot \mathrm{M}] \mathrm{X}_{\mathrm{n}}$ $\left(\mathrm{M}=\mathrm{K}, \mathrm{Ca}, \mathrm{Eu}, \mathrm{Er} ; \mathrm{X}=\mathrm{Cl}, \mathrm{I}\right.$, and $\left.\mathrm{NO}_{3}\right) .^{11}$<smiles></smiles>

3<smiles>CC(C)=NCCN=C(C)c1cccc(C(C)=NCCN=C(C)c2cccc(C)n2)n1</smiles>

4
The chemical structures of 2 and $[2 \cdot M] X_{n}$ were confirmed by spectroscopic methods and X-ray crystallography (see below). ${ }^{10-12}$ Figure 1 shows the ${ }^{1} \mathrm{H}$ NMR spectra of 2 and [2. Ca] $\mathrm{Cl}_{2}$ in $\mathrm{CDCl}_{3}$. The ${ }^{1} \mathrm{H}$ and ${ }^{13} \mathrm{C}$ NMR peaks of 2 cannot be assigned definitively because of the complex signal pattern, although the signals became broader and simpler at $130{ }^{\circ} \mathrm{C}$ in DMSO- $d_{6}$. The stereoisomerism of 2 in solution is suggested to be due to the $\mathrm{E} / \mathrm{Z}$ isomerization of the thioimidate group. ${ }^{6 \mathrm{~d}}$ In contrast, complexation with a $\mathrm{Ca}(\mathrm{II})$ ion is considered to fix the geometry of $\mathbf{2}$ and results in a simplified ${ }^{1} \mathrm{H}$ NMR spectrum, as shown in Figure 1(b). For $[2 \cdot \mathrm{Eu}]\left(\mathrm{NO}_{3}\right)_{3}$ and $[2 \cdot \mathrm{Er}]\left(\mathrm{NO}_{3}\right)_{3}$, the complexation of the paramagnetic metals leads to significant changes in the ${ }^{1} \mathrm{H}$ NMR spectrum, ${ }^{13}$ and the photoluminescence spectrum of $[2 \cdot \mathrm{Eu}]\left(\mathrm{NO}_{3}\right)_{3}$ exhibits a sharp emission peak at $616 \mathrm{~nm}$ in $\mathrm{CH}_{3} \mathrm{CN}$ due to the ${ }^{5} \mathrm{D}_{0}$ $\rightarrow{ }^{7} \mathrm{~F}_{2}$ transition of the $\mathrm{Eu}(\mathrm{III})$ ion. ${ }^{7,8}$ The emission intensity of $[2 \cdot \mathrm{Eu}]\left(\mathrm{NO}_{3}\right)_{3}$ is about four times stronger than that of a $\mathrm{Eu}(\mathrm{III})$ complex of the macrocyclic hexaaza Schiff base ligand $\left([4 \cdot \mathrm{Eu}]\left(\mathrm{NO}_{3}\right)_{3}\right)$. $^{7 \mathrm{f}, \mathrm{g}}$

To examine the affinity of $\mathbf{2}$ toward metal ions, competitive complexation experiments on $\mathbf{2}$ and the known macrocyclic ligand, dibenzo-18-crown-6(DB18C6), ${ }^{14}$ were carried out by ${ }^{1} \mathrm{H}$ NMR spectroscopy. The NMR experiments using
$1: 1$ mixtures of $[2 \cdot \mathrm{Ca}] \mathrm{Cl}_{2}$ with $\mathrm{DB} 18 \mathrm{C} 6$ and of $[2 \cdot \mathrm{Eu}]\left(\mathrm{NO}_{3}\right)_{3}$ with DB18C6 showed that 2 exhibited much higher affinity toward $\mathrm{Ca}(\mathrm{II})$ and $\mathrm{Eu}(\mathrm{III})$ ions than DB18C6. In neither case was any free 2 detected. In contrast, the NMR spectrum of a 1:1 mixture of $[2 \cdot \mathrm{K}] \mathrm{I}$ with DB18C6 showed free 2 , indicating less affinity of 2 toward $\mathrm{K}^{+}$ion than that of DB18C6.

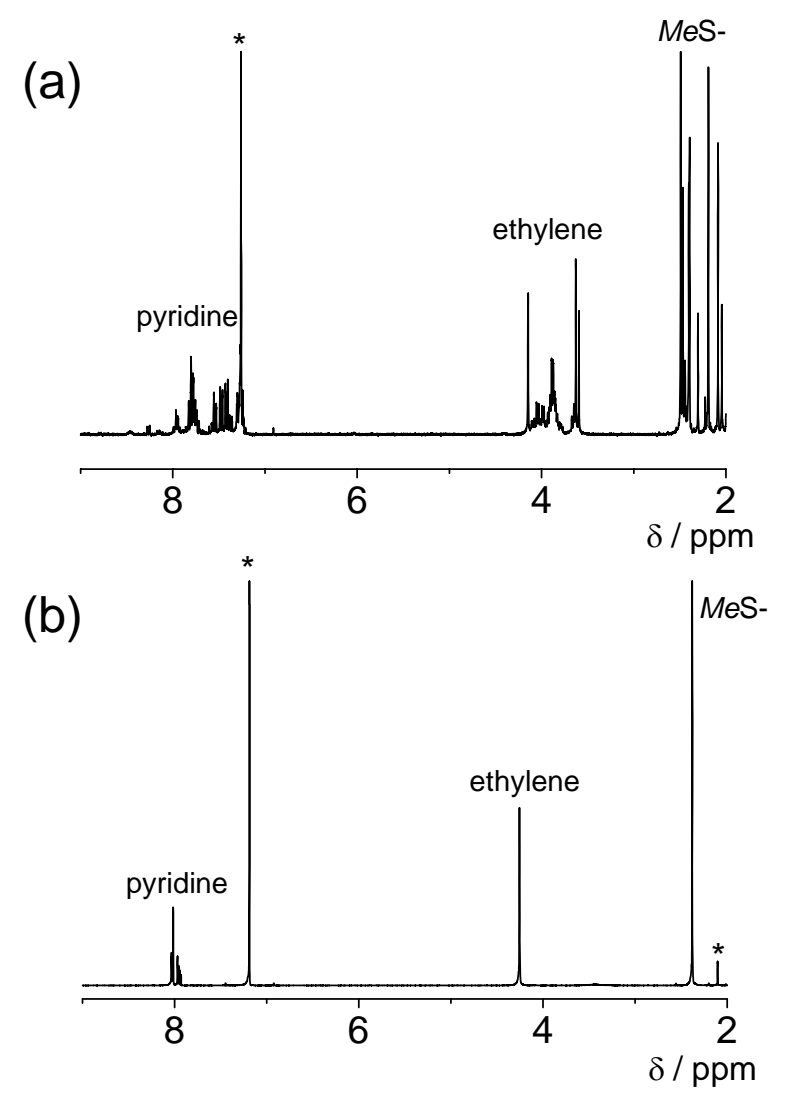

Figure 1. ${ }^{1} \mathrm{H}$ NMR spectra of (a) 2 and (b) $[2 \cdot \mathrm{Ca}] \mathrm{Cl}_{2}\left(400 \mathrm{MHz}, \mathrm{CDCl}_{3}\right.$, 298 K). Peaks marked with an asterisk * are due to solvent impurities.

The ORTEP drawings of $\mathbf{2},[\mathbf{2} \cdot \mathrm{Ca}] \mathrm{Cl}_{2}$, and $[\mathbf{2} \cdot \mathrm{Eu}]\left(\mathrm{NO}_{3}\right)_{3}$ are presented in Figure 2. ${ }^{12}$ In the X-ray quality single crystals of $\mathbf{2}$, the asymmetric unit of $\mathbf{2}$ consists of two halves of two independent and discrete molecules. Figure 2(a) indicates that $\mathbf{2}$ adopts an approximately $C_{2 \mathrm{v}}$ conformation, and the two pyridine rings are heavily tilted in opposite directions from the center circle with dihedral angles of 39.20 and $46.31^{\circ}$, presumably due to electronic repulsion between the lone pair electrons of the nitrogen atoms. In contrast, as shown in Figures 2(b) and (c), the complexation of 2 with metal ions leads to a well-fitted accommodation of a metal ion in the cavity, which induces reductions in the dihedral angles between the pyridine rings and the macrocyclic framework of 32.25 and $24.16^{\circ}$, respectively. For $[2 \cdot \mathrm{Eu}]\left(\mathrm{NO}_{3}\right)_{3}$, the two pyridine rings are twisted with a dihedral angle of $48.33^{\circ}$ upon coordination to a $\mathrm{Eu}(\mathrm{III})$ ion. In both complexes, the metal atom is bound to all six nitrogen atoms of $\mathbf{2}$ with $\mathrm{Ca}-\mathrm{N}$ and $\mathrm{Eu}-\mathrm{N}$ atom distances of 2.708-2.825 and 2.598-2.631 $\AA$, respectively. The Eu-N 
atom distances are consistent with those reported for the $\mathrm{Eu}$ complexes of the macrocyclic hexaaza Schiff base ligand $(2.564-2.747 \AA){ }^{15}$

In contrast to extensive studies of the metal complexes with $\mathbf{4}^{3,7,8}$ to our knowledge, the isolation of $\mathbf{4}$ has not been successful presumably due to the poor resistance of the imine bonds of $\mathbf{4}$ toward hydrolysis. ${ }^{7 d, e, 8 b}$ The resistance of 2 toward hydrolysis in basic and acidic media was evaluated using ${ }^{1} \mathrm{H}$ NMR spectroscopy in $\mathrm{CDCl}_{3}$. The treatment of a $\mathrm{CDCl}_{3}$ solution of 2 with aqueous $\mathrm{NaOH}$ gave essentially the same NMR spectrum after 1 week. The addition of aqueous trifluoroacetic acid led to the protonation of 2; however, the spectrum remained unchanged over 1 week. The treatment of the solution with $\mathrm{Na}_{2} \mathrm{CO}_{3}$ gave essentially the same NMR spectrum as that of the original 2. Therefore, 2 seems to be a stable ligand and can serve as a good ionophore for various metal ions.

(a)

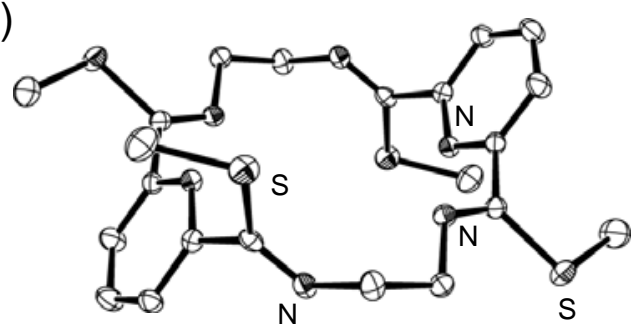

(b)

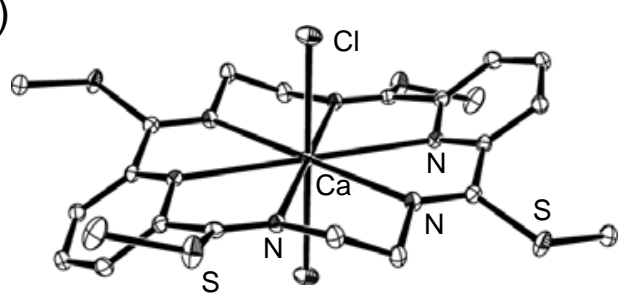

(c)

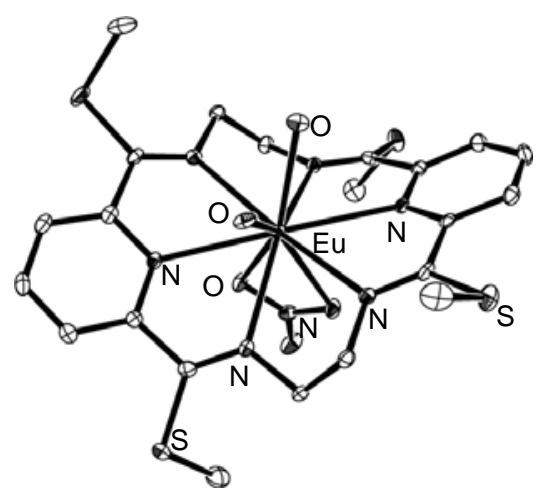

Figure 2. X-ray crystal structures of (a) 2, (b) $[2 \cdot \mathrm{Ca}] \mathrm{Cl}_{2}$, and (c) $[2 \cdot \mathrm{Eu}]\left(\mathrm{NO}_{3}\right)_{3}$ with thermal ellipsoids drawn at the $50 \%$ probability level. One of the two crystallographically independent molecules of $\mathbf{2}$ is shown. Hydrogen atoms, anions, and solvated molecules are omitted for simplicity.

As described above, $\mathbf{1}$ is not only a good anion receptor but also a useful starting material for the preparation of a new macrocyclic thioimidate 2 . 2 is a stable macrocyclic ligand that forms complexes with metal ions. This synthetic protocol is practical for the design of various macrocyclic ligands and ionophores for metal ions.

\section{Acknowledgments}

The authors are grateful to Dr. T. Koizumi, Dr. H. Fukumoto, and Dr. Y. Nakamura of Tokyo Institute of Technology for their experimental support. The authors are grateful to the Chemical Analysis Center of University of Tsukuba, for measurements of X-ray crystallography and NMR spectra.

\section{References}

1. (a) Lehn, L. M. Supramolecular Chemistry-Concepts and Perspectives; VCH: Veinheim, 1995. (b) Rebek, J. Jr. Acc. Chem. Res. 1999, 32, 278

2. (a) Choi, K.; Hamilton, A. D. Coord. Chem. Rev. 2003, 240, 101. (b) Bondy, C. R.; Loeb, S. J. Coord. Chem. Rev. 2003, 240, 77. (c) Gale, P. A. Coord. Chem. Rev. 2003, 240, 191.

3. (a) Lindoy, L. F. The Chemistry of Macrocyclic Ligand Complexes; Cambridge University Press: New York, 1989. (b) Hancock, R. D. Acc. Chem. Res. 1990, 23, 253. (c) Nabeshima, T.; Yoshihiro, Y.; Saiki, T.; Akine, S.; Horn, E. J. Am. Chem. Soc. 2003, 125, 28.

4. (a) Inoue, Y.; Kanbara, T.; Yamamoto, T. Tetrahedron Lett. 2003, 44, 5167. (b) Hossain, Md. A.; Kang, S. O.; Llinares, J. M.; Powell, D.; Bowman-James, K. Inorg. Chem. 2003, 42, 5043. (c) Inoue, Y.; Kanbara, T.; Yamamoto, T. Tetrahedron Lett. 2004, 45, 4603.

5. (a) Jagodziński, T. S. Chem. Rev. 2003, 103, 197. (b) Murai, T. Top Curr. Chem. 2005, 251, 247. (c) Murai, T.; Aso, H.; Tatematsu, Y.; Itoh, Y.; Niwa, H.; Kato, S. J. Org. Chem. 2003, 68, 8514 .

6. (a) Shiosaki, K. Comprehensive Organic Synthesis, Trost, B. M.; Fleming, I., Eds.; Pergamon Press: New York, 1991; Vol. 2, p. 865. (b) Ach, D.; Reboul, V.; Metzner, P. Eur. J. Org. Chem. 2002, 2573. (c) Casadei, M. A.; Rienzo, B. D.; Moracci, F. M. Synth. Commun. 1983, 13, 753. (d) Walter, W.; Meese, C. O. Chem. Ber. 1977, 110, 2463. (e) Masson, S.; Mothes, V.; Thuillier, A. Tetrahedron, 1984, 40, 1580.

7. (a) Hernandez-Molina, R.; Mederos, A. Comprehensive Coordination Chemistry II; McCleverty, J. A.; Meyer, Thomas J. Eds.: Elsevier, Oxford, 2004, 1. (b) Brooker, S. Eur. J. Inorg. Chem. 2002, 2535. (c) Bell, T. W.; Guzzo, F.; Drew, M. G. B. J. Am. Chem. Soc. 1991, 113, 3115. (d) De Cola, L.; Smailes, D. L.; Vallarino, L. M. Inorg. Chem. 1986, 25, 1729. (e) Benetollo, F.; Bombieri, G.; Fonda, K. K.; Polo, A.; Quagliano, J. R.; Vallarino, L. M. Inorg. Chem. 1991, 30, 1345. (f) Kasuga, K.; Moriguchi, T.; Yamada, K.; Hiroe, M.; Handa, M.; Sogabe, K. Polyhedron 1994, 13, 159. (g) Arif, A. M.; Backer-Dirks, J. D. J.; Gray, C. J.; Hart, F. A.; Hursthouse, M. B. J. Chem. Soc. Dalton Trans. 1987, 1665.

8. (a) Morrow, J. R.; Buttrey, L. A.; Shelton, V., M.; Berback, K. A. J. Am. Chem. Soc. 1992, 114, 1903. (b) Voss Jr., D. A.; Buttrey-Thomas, L. A.; Janik, T. S.; Churchill, M. R.; Morrow, J. R. Inorg. Chim. Acta 2001, 317, 149.

9. Nirantar et al. have reported synthesis of macrocyclic thioimidate ligands, however, any complex formation could not be detected; Nirantar, S. S.; Mashraqui, S. H. Indian J. Chem. Sect. B 1995, 34, 1102. 
10. Macrocyclic thioimidate 2: 1 (400 $\mathrm{mg}, 0.9 \mathrm{mmol}$ ) was added to a $\mathrm{CH}_{2} \mathrm{Cl}_{2}(100 \mathrm{~mL})$ solution of $\mathrm{Me}_{3} \mathrm{OBF}_{4}(1270 \mathrm{mg}, 8.6$ $\mathrm{mmol})$. The reaction mixture was refluxed for $24 \mathrm{~h}$. After the reaction, the reaction mixture was washed with aqueous $\mathrm{NaOH}$ and the product was extracted with $\mathrm{CHCl}_{3}$. The organic layer was separated, and the solvent was evaporated. The crude product was thoroughly washed with $\mathrm{CH}_{3} \mathrm{CN}$ to give a white powder of $2(270 \mathrm{mg}, 60 \%$ yield $)$. FAB-MS: $\mathrm{m} / \mathrm{z} 503[\mathrm{M}+\mathrm{H}]^{+}$. ${ }^{1} \mathrm{H}$ NMR $\left(400 \mathrm{MHz}\right.$ in $\left.\mathrm{CDCl}_{3}\right): \delta 7.81-7.24$ $(\mathrm{m}, 6 \mathrm{H}), 4.12-3.59(\mathrm{~m}, 8 \mathrm{H}), 2.50-2.04(\mathrm{~m}, 12 \mathrm{H}) .{ }^{13} \mathrm{C} \mathrm{NMR}$ $\left(100 \mathrm{MHz}\right.$ in $\left.\mathrm{CDCl}_{3}\right): \delta 164.9-164.0,155.6-152.2,138.1-$ 136.6, 122.9-122.0, 55.3-53.8, 16.0-13.1. Anal. calcd for $\mathrm{C}_{22} \mathrm{H}_{26} \mathrm{~N}_{6} \mathrm{~S}_{4}: \mathrm{C}, 52.56 ; \mathrm{H}, 5.21 ; \mathrm{N}, 16.72$. Found: $\mathrm{C}, 52.52 ; \mathrm{H}$, $5.07 ; \mathrm{N}, 16.60$.

11. $[2 \cdot \mathrm{Ca}] \mathrm{Cl}_{2}: \mathrm{CaCl}_{2}(33 \mathrm{mg}, 0.3 \mathrm{mmol})$ was added to a $\mathrm{CHCl}_{3}(2$ $\mathrm{mL})$ solution of $2(25 \mathrm{mg}, 0.05 \mathrm{mmol})$, and the reaction mixture was stirred at room temperature for $24 \mathrm{~h}$. The reaction mixture was filtrated and the solvent in the filtrate was removed by evaporation. The complex was purified by recrystallization from $\mathrm{CH}_{3} \mathrm{CN} /$ ether to give a white powder of [2. Ca] $\mathrm{Cl}_{2}$ (15 mg, 50\% yield). FAB-MS: m/z $577[\mathrm{M}-\mathrm{Cl}]^{+}$. HRMS: calcd for $\mathrm{C}_{22} \mathrm{H}_{26} \mathrm{~N}_{6} \mathrm{CaClS}_{4}$ : 577.0416. Found: 577.0410. ${ }^{1} \mathrm{H}$ NMR $\left(400 \mathrm{MHz}\right.$ in $\left.\mathrm{CDCl}_{3}\right): \delta 8.03(\mathrm{~d}, J=7.8$ $\mathrm{Hz}, 4 \mathrm{H}), 7.95$ (t, $J=7.8 \mathrm{~Hz}, 2 \mathrm{H}), 4.25(\mathrm{~s}, 8 \mathrm{H}), 2.37$ (s, 12H). ${ }^{13} \mathrm{C}$ NMR $\left(100 \mathrm{MHz}\right.$ in $\left.\mathrm{CDCl}_{3}\right): \delta 165.3,153.3,139.1,126.0$, $55.1,17.1$. Other metal complexes of 2 were prepared analogously. [2·K]I: 46\% yield. FAB-MS: m/z 541 [M-I] $]^{+}$. HRMS: calcd for $\mathrm{C}_{22} \mathrm{H}_{26} \mathrm{~N}_{6} \mathrm{KS}_{4}: 541.0739$. Found: 541.0751 . ${ }^{1} \mathrm{H}$ NMR $\left(400 \mathrm{MHz}\right.$ in $\left.\mathrm{CDCl}_{3}\right): \delta 8.02(\mathrm{t}, J=7.8 \mathrm{~Hz}, 2 \mathrm{H})$, $7.71(\mathrm{~d}, J=7.8 \mathrm{~Hz}, 4 \mathrm{H}), 3.95(\mathrm{~s}, 8 \mathrm{H}), 2.25(\mathrm{~s}, 12 \mathrm{H}) .{ }^{13} \mathrm{C}$ NMR (100 MHz in $\left.\mathrm{CDCl}_{3}\right): \delta 165.3,154.5,138.0,124.5$, 53.8, 16.5. [2·Eu] $\left(\mathrm{NO}_{3}\right)_{3}: 48 \%$ yield. FAB-MS: m/z 779 [M$\left.\left(\mathrm{NO}_{3}\right)\right]^{+}$. HRMS: calcd for $\mathrm{C}_{22} \mathrm{H}_{26} \mathrm{~N}_{8} \mathrm{EuO}_{6} \mathrm{~S}_{4}: 779.0065$. Found: 779.0052. ${ }^{1} \mathrm{H}$ NMR (400 MHz in $\left.\mathrm{CD}_{3} \mathrm{CN}\right): \delta 4.74(\mathrm{t}$, $J=7.8 \mathrm{~Hz}, 2 \mathrm{H}), 2.77(\mathrm{~d}, J=7.8 \mathrm{~Hz}, 4 \mathrm{H}), 1.87(\mathrm{~s}, 12 \mathrm{H}), 0.79$ $(\mathrm{s}, 8 \mathrm{H}) .{ }^{13} \mathrm{C} \mathrm{NMR}\left(100 \mathrm{MHz}\right.$ in $\left.\mathrm{CD}_{3} \mathrm{CN}\right): \delta 146.4,145.3$, 127.6, 103.05, 63.8, 22.7. [2-Er] $\left(\mathrm{NO}_{3}\right)_{3}: 71 \%$ yield. ESI-MS: $\mathrm{m} / \mathrm{z} 792\left[\mathrm{M}-\left(\mathrm{NO}_{3}\right)\right]^{+}, 365\left[\mathrm{M}-2\left(\mathrm{NO}_{3}\right)\right]^{2+}, 223\left[\mathrm{M}-3\left(\mathrm{NO}_{3}\right)\right]^{3+}$. ${ }^{1} \mathrm{H}$ NMR $\left(400 \mathrm{MHz}\right.$ in $\left.\mathrm{CD}_{3} \mathrm{CN}\right): \delta 20.18(\mathrm{~s}, 8 \mathrm{H}), 19.60(\mathrm{br}$, $4 \mathrm{H}), 15.63(\mathrm{br}, 2 \mathrm{H}), 2.69(\mathrm{~s}, 12 \mathrm{H})$.

12. Crystal data of $2 \cdot 2 \mathrm{CH}_{3} \mathrm{CN}: \mathrm{C}_{26} \mathrm{H}_{32} \mathrm{~N}_{8} \mathrm{~S}_{4}, M=584.83$, triclinic, $P$ 1bar, $a=9.7533(13), b=11.1288(17), c=15.206(2) \AA, \alpha=$ $87.059(7)^{\circ}, \beta=73.836(8)^{\circ}, \gamma=69.692(4)^{\circ}, V=1484.8(4) \AA^{3}$, $Z=2, D_{\text {calcd }}=1.308 \mathrm{~g} / \mathrm{cm}^{3}, \mu(\operatorname{MoK} \alpha)=3.506 \mathrm{~cm}^{-1}, T=113$ $\mathrm{K}, F(000)=616$, observed reflections 6186 (all data), variables $375, R_{1}=0.0327(I>2 \sigma(I)), R=0.0391, R_{w}=$
0.0521, GOF $=0.992$. Crystal data of [2.K]I: $\mathrm{C}_{22} \mathrm{H}_{26} \mathrm{IKN}_{6} \mathrm{~S}_{4}$, $M=668.73$, triclinic, $P 1$ bar, $a=9.615(3), b=10.868(4), c=$ 13.561(5) $\AA, \alpha=97.686(5)^{\circ}, \beta=103.203(6)^{\circ}, \gamma=89.845(5)^{\circ}$, $V=1366.6(8) \AA^{3}, Z=2, D_{\text {calcd }}=1.625 \mathrm{~g} / \mathrm{cm}^{3}, \mu(\mathrm{MoK} \alpha)=$ $16.536 \mathrm{~cm}^{-1}, T=113 \mathrm{~K}, F(000)=672$, observed reflections 5507 (all data), variables 333, $R_{1}=0.1111(I>2 \sigma(I)), R=$ $0.1129, R_{w}=0.2153, \mathrm{GOF}=1.055$. Despite several attempts, $\mathrm{X}$-ray quality single crystals of $[2 \cdot \mathrm{K}] \mathrm{I}$ could not be obtained. Crystal data of $[2 \cdot \mathrm{Ca}] \mathrm{Cl}_{2} \cdot \mathrm{CH}_{3} \mathrm{CN}: \mathrm{C}_{24} \mathrm{H}_{29} \mathrm{CaCl}_{2} \mathrm{~N}_{7} \mathrm{~S}_{4}, M=$ 654.77, monoclinic, $P 2_{1} / c, a=9.514(3), b=10.257(3), c=$ 16.045(5) $\AA, \beta=91.9400(11)^{\circ}, V=1564.8(9) \AA^{3}, Z=2$, $D_{\text {calcd }}=1.390 \mathrm{~g} / \mathrm{cm}^{3}, \mu(\operatorname{MoK} \alpha)=6.642 \mathrm{~cm}^{-1}, T=113 \mathrm{~K}$, $F(000)=680$, observed reflections 3408 (all data), variables $203, R_{1}=0.0435(I>2 \sigma(I)), R=0.0452, R_{w}=0.1053, \mathrm{GOF}=$ 0.984. Crystal data of $[2 \cdot \mathrm{Eu}]\left(\mathrm{NO}_{3}\right)_{3} \cdot 2 \mathrm{H}_{2} \mathrm{O}: \mathrm{C}_{22} \mathrm{H}_{30} \mathrm{EuN}_{9} \mathrm{O}_{11} \mathrm{~S}_{4}$, $M=876.73$, monoclinic, $C 2 / c, a=16.023(2), b=$ 15.4693(19), $c=12.6922(16) \AA, \beta=99.2197(16)^{\circ}, V=$ $3105.2(7) \AA^{3}, Z=4, D_{\text {calcd }}=1.875 \mathrm{~g} / \mathrm{cm}^{3}, \mu(\operatorname{MoK} \alpha)=23.571$ $\mathrm{cm}^{-1}, T=113 \mathrm{~K}, F(000)=1760$, observed reflections 3430 (all data), variables $235, R_{1}=0.0214(I>2 \sigma(I)), R=0.0228$, $R_{w}=0.0287, \mathrm{GOF}=0.934$. Crystal data of $[2 \cdot \mathrm{Er}]\left(\mathrm{NO}_{3}\right)_{3}$ : $\mathrm{C}_{22} \mathrm{H}_{26} \mathrm{ErN}_{9} \mathrm{O}_{9} \mathrm{~S}_{4}, M=856.00$, triclinic, $P 1$ bar, $a=8.579(2), b$ $=11.702(3), c=15.331(4) \AA, \alpha=94.573(4)^{\circ}, \beta=$ $100.778(4)^{\circ}, \gamma=102.607(3)^{\circ}, V=1463.8(6) \AA^{3}, Z=2, D_{\text {calcd }}$ $=1.942 \mathrm{~g} / \mathrm{cm}^{3}, \mu(\operatorname{MoK} \alpha)=32.146 \mathrm{~cm}^{-1}, T=113 \mathrm{~K}, F(000)=$ 850 , observed reflections $5573(I>2 \sigma(I))$, variables $432, R_{1}=$ $0.0194, R_{w}=0.0264, \mathrm{GOF}=0.954$.

13. Fonda, K. K.; Vallarino, L. M. Inorg. Chim. Acta 2002, 334, 403.

14. (a) Buschmann, H.-J.; Cleve, E.; Denter, U.; Schollmeyer, E. J. Phys. Org. Chem. 1997, 10, 781. (b) Pedersen, C. J. J. Am. Chem. Soc. 1967, 89, 7017.

15. Churchill, M. R.; Lake, C. H.; Buttrey, L. A.; Morrow, J. R. J. Coord. Chem. 2000, 50, 339.

\section{Supplementary Material}

ORTEP drawings of $[2 \cdot \mathrm{K}] \mathrm{I}$ and $[2 \cdot \mathrm{Er}]\left(\mathrm{NO}_{3}\right)_{3}$. Crystallographic data for the structural analysis have been deposited with the Cambridge Crystallographic Data Center; publication numbers CCDC $656961\left(2 \cdot 2 \mathrm{CH}_{3} \mathrm{CN}\right)$, $656962([2 \cdot \mathrm{K}] \mathrm{I}), 656963\left([2 \cdot \mathrm{Ca}] \mathrm{Cl}_{2} \cdot \mathrm{CH}_{3} \mathrm{CN}\right), 656964$ $\left([2 \cdot \mathrm{Eu}]\left(\mathrm{NO}_{3}\right)_{3} \cdot 2 \mathrm{H}_{2} \mathrm{O}\right)$, and $656965\left([2 \cdot \mathrm{Er}]\left(\mathrm{NO}_{3}\right)_{3}\right)$. 